Citation: D.C. Stix, T. Jolls (2020) Promoting media literacy learning - a comparison of various media literacy models. Media Education 11(1): 15-23. doi: 10.36253/me-9091

Received: March 2020

Accepted: May 2020

Published: July 2020

Copyright: (c) 2020 D.C. Stix, T. Jolls. This is an open access, peer-reviewed article published by Firenze University Press (http://www.fupress.com/me) and distributed under the terms of the Creative Commons Attribution License, which permits unrestricted use, distribution, and reproduction in any medium, provided the original author and source are credited.

Data Availability Statement: All relevant data are within the paper and its Supporting Information files.

Competing Interests: The Author(s) declare(s) no conflict of interest.

\section{Promoting media literacy learning - a comparison of various media literacy models}

\section{Promuovere la media literacy. Una comparazione tra differenti modelli di media literacy}

\author{
Daniela Cornelia Stix ${ }^{1}$, Tessa Jolls ${ }^{2}$ \\ ${ }^{1}$ University of Cologne, Germany \\ ${ }^{2}$ Center for Media Literacy, USA \\ E-mail: daniela.stix@uni-koeln.de; tjolls@medialit.com
}

\begin{abstract}
With our paper we analyze four renowned media literacy models from Germany, UK and USA to derive, through comparisons, the necessary core competencies which apply to all professions and that are valid across disciplines. In the results, as key-competencies, we identified critical analysis as essential to be able to act as selfdetermined individuals in so called mediatized societies. Further results show that media literacy learning can be developed in formal learning settings, as well as in nonformal and in informal learning settings that complement each other. Media literacy promotion is therefore a cross-disciplinary task for all kinds of professionals in the educational and social systems. With referring to the concept of mediatization, we also show the deep social impact of media on people's lives and explain why it is helpful to see media literacy learning as part of lifelong learning. We finally conclude, that the terms «teaching media literacy» and «media literacy education» are no longer applicable. Instead, we highly recommend the terms «promoting media literacy» and «media literacy learning». By seeing media literacy learning as a cross-disciplinary task and as a process of lifelong learning, our findings can help to unify discussions about media literacy on a global level.
\end{abstract}

Keywords: media literacy models, teaching media literacy, promoting media literacy learning, media literacy education, media literacy competencies. 
questo articolo mostriamo anche il profondo impatto sociale dei media sulla vita delle persone e spieghiamo perché è utile vedere l'apprendimento della media literacy come parte dell'apprendimento permanente. Di conseguenza raccomandiamo di abbandonare vecchie terminologie in favore di termini quali 'promozione della digital literacy' e 'apprendimento della digital literacy'. Compiti interdisciplinari che necessitano di una discussione in grado di convergere e unificare le discussioni che sino ad ora ci sono state attorno a questi temi.

Parole Chiave: modelli di media literacy, media literacy, media education, competenze mediali.

\section{INTRODUCTION \& RELEVANCE}

Almost every country has now recognized that media education is significant. Educational concepts and media literacy competence models are developed. If you look from a meta-level, you notice a certain kind of national border. Many of these national concepts and models are often only known and only received in their respective countries. Many different national models stand side by side with no reference.

With this paper we will take a first step towards crossing the border. We are going to present and compare two prominent media literacy models from Germany, one prominent media literacy model from UK, and one prominent media literacy model from USA. These models reflect various times, purposes and backgrounds, which provide different contexts for their development. We will analyze and compare the four presented media literacy models according to World-view, Agency, Structures, and Objectives. By comparing and contrasting we want to show similarities and differences as well as possible mutual extensions and additions. Furthermore, we hope that at least these four models will achieve a higher degree of international recognition, enriching both national discourse and the international discourse on media literacy promotion.

\section{MEDIA LITERACY MODELS}

Our sampling consists of two prominent media literacy models from Germany (four Dimensions of Media Literacy by Baacke, 1996 and Magedburger Model of Media Education by Jörissen/Marotzki, 2009), one prominent model from UK (18 Principles by Masterman, 1989), and one prominent model from USA (Q/Tips and the Empowerment Spiral by Thoman, 1993; Jolls/Wilson, 2014). The models vary in regards to the times, purposes and backgrounds they were developed. We will present contexts for each of the four models and then summarize the core statements of the respective models.

\subsection{Four dimensions of media literacy (Baacke, 1996)}

CONTEXT: The model of «media-related competency» was conceptually prepared by Dieter Baacke in his 1973 habilitation about communication competency. According to Baacke, media literacy is a requirement for an adequate understanding of media communication tools and for self-determined usage of these. Media literacy enables the user to handle the new possibilities of information processing confidently, to participate in the progress and to navigate in it. Beyond the individual, Baacke also demands media literacy practitioners to look broader and to consider the economic, social, cultural and technical implications of the "information society» (Baacke, 1996). In the 1990s his model was adopted more and more in science, in the (media) pedagogical practice, and in politics and became particularly famous. Baacke transferred his concept to a low-threshold project learning arrangement for future teachers. This practical learning project later was used as an argument to bring the internet into schools to promote a participation process. Baackes' media literacy model is the most famous one in Germany with practitioners and scientists (Baacke, 2001).

CONTENT: In Baackes' model one finds four dimensions: Media Criticism, Media Knowledge, Media Usage, and Media Production.

1. Media Criticism means to differentiate and identify existing knowledge and experiences in a reflective way. The dimension of Media Criticism consists of the sub-dimensions a) analytics (background knowledge to question media developments), b) reflection (relate and apply ones' analytical and other knowledge to oneself and one's personal actions, and c) ethics (coordinates and defines analytic thinking and reflexive reference as socially responsible).

2. Media Knowledge means pure knowledge of today's media and media systems including the two sub-dimensions a) informative (classical knowledge stocks: 
journalist ethics, genres), and b) instrumental (ability to operate the new devices).

3. The dimension Media Usage is composed of a) receptive-applying (program-use competency, seeing movies demands reception skills), and b) interactive action (making use of today's multitude of options for action and interaction).

4. Media Production is based on the fact that media are constantly changing. For Baacke media production can be innovative (further development of the media system within the applied logic) and/or creative (crossing boundaries of communication routines, new dimensions of design and theming).

\subsection{Eighteen basic principles (Masterman, 1989)}

CONTEXT: Len Masterman is a now-retired university professor and teacher in the UK. He first perceived that media education was not about studying a particular medium or topic or content -- it was about studying the representation of a particular topic or content through media channels. "Media education is nothing if it is not an education for life» (Morgenthaler, 2010, n.pag.).

Masterman's objectives were to change views on the teacher's role, which is not to advocate a particular view - but instead should be a promotion of reflexivity and analytical skills regarding media, and one's own view. Masterman wanted to liberate pupils from the expertise of the teacher, and to challenge the dominant hierarchical transmission of knowledge which takes place - until nowadays - in most classrooms (Morgenthaler, 2010). Masterman is called the first person who proposed the serious study of the mass media in schools. He developed a certain set of key ideas and concepts that provide a way of studying, in a rigorous and disciplined way, the diverse range of media content (Morgenthaler, 2010).

CONTENT: Highlights of Masterman's Eighteen Principles include some of the following statements.

- Content, in Media Education, is a means to an end. That end is the development of transferable analytical tools rather than alternative content.

- Ideally, evaluation in Media Education means student self-evaluation, both formative and summative.

- Indeed, Media Education attempts to change the relationship between teacher and student by offering both objects for reflection and dialogue.

- Media Education is essentially active and participatory, fostering the development of more open and democratic pedagogies. It encourages students to take more responsibility for and control over their own learning, to engage in joint planning of the syl- labus, and to take longer-term perspectives on their own learning.

- Media Education involves collaborative learning. It is group focused. It assumes that individual learning is enhanced not through competition but through access to the insights and resources of the whole group.

- Media Education is a holistic process. Ideally it means forging relationships with parents, media professionals and teacher-colleagues.

- Media Education is committed to the principle of continuous change. It must develop in tandem with a continuously changing reality.

- Underlying Media Education is a distinctive epistemology. Existing knowledge is not simply transmitted by teachers or 'discovered' by students. It is not an end but a beginning. It is the subject of critical investigations and dialogue out of which new knowledge is actively created by students and teachers.

\subsection{Q/TIPS (Thoman, 1993 and Jolls/Wilson, 2014)}

CONTEXT: The core concepts of media literacy were originally developed in Canada in the 1980's by leading practitioners including Barry Duncan and John Puengente, whose work was informed by Masterman's approach to media literacy education. The Canadians posed eight core concepts; these were later adapted in the U.S. to comprise five core concepts (Thoman, 1993) that describe how global media symbolic systems operate: All media messages are constructed (Authorship); Media messages are constructed using a creative language with its own set of rules (Techniques/Format); Different people experience the same media message differently (Audience); Media have embedded values and points of view (Framing/Content); and most media messages are organized for profit and/or power (Purpose). Using these concepts can afford the critical analysis of media messages in an Empowerment Spiral of awareness, analysis, reflection and action, an action learning model developed through the work of Paulo Freire, a Brazilian educator. Utilizing these core concepts provides a common base for critical analysis of the global symbolic media system, and for building pedagogy around the understanding of these concepts in acquiring, contextualizing and applying content knowledge. These concepts provide consistent and transferable knowledge that can be organized into a pedagogy and taught globally.

From a pedagogy standpoint, it's best to make learning a process of inquiry and discovery -- something that students and teachers alike use to learn together. This 
adheres to Masterman's principles.

CONTENT: Jolls'/Willson's, model builds on the previously presented concepts and summarizes them in five deconstructive key questions for media users, called Questions/TIPS (Q/TIPS):

- Authorship: Who created this message and why are they sending it?

- Techniques: What techniques are being used to attract my attention

- Audience: What lifestyles, values and points of view are represented in the message?

- Framing: How might different people understand this message differently from me?

- Purpose: What is omitted from this message?

These five deconstructing questions cannot only be used to deconstruct and analyse media but also be applied when producing one's own media products.

\subsection{Magdeburger model of media education (Jörissen/ Marotzki, 2009)}

CONTEXT: The German university professors Winfried Marotzki and Benjamin Jörissen published their concept of media education in 2009. Before, the German scientific community had a lively and long-lasting discussion about the terms of media literacy (Medienkompetenz) and media education (Medienbildung). The term media literacy is a popular term that is used (and miss-used) in praxis and theory as well as in many different professional fields (see Gapski, 2001, p. 30). Through his prominence the term media literacy is not very accurate and subsumes a variety of concepts which mostly have a perspective on usage practice. Whereas the less common term media education is a more heuristic one, the concept of media education is not supposed to be transferred into practice and it is not didactics of media pedagogy. "Media education does not primarily refer to the media as an object -- rather, media literacy is the framework of all education» (Jörissen, 2013). As noted above, disposition knowledge is a necessary, but not yet sufficient, condition of media education. It is not enough to understand how to use the technology itself; critical reflection must be part of the process that users undertake. Critical reflection is particularly required when it comes to risk structures and cultural implications of modern technologies, and when questions of the possible consequences are addressed.

CONTENT (with reference to the paper Medienbildung in 5 Sätzen by Jörrissen, 2013):

1. Media education is education in a media-mediated and mediatized world.
2. Media education is therefore not just education through the media (media literacy) and not just education with the media (elearning).

3. "Education" means changes in the way individuals see and perceive the world (and themselves) in such a way that in an increasingly complex world, they are coping with less and less predictable biographies and careers, and gaining orientation and behaving in a critical-participatory way towards this world.

4. The media essentially determine the structures of worldviews, both at a cultural and individual level: Oral cultures, scripture and book cultures, visual cultures and digitally networked cultures each bring different possibilities of articulation (of thinking, of expression, of communication, the sciences, the arts).

5. Media education is therefore the name for the fact that the world and self-relations of people with medial (or constituted) cultural worlds emerge, that they change with them - and, above all, that education processes can produce new things: new forms of articulation, new cultural / individual perspectives and not least, new media structures.

\section{COMPARING AND CONTRASTING THE MEDIA LITERACY MODELS}

The following section analyzes and compares the four presented media literacy models according to World-view, Agency, Structures, and Objectives. Subsequently, the recurring key competencies of the models will be summarized.

\subsection{World-view}

Each of the four models sees media literacy as a core element in what Friedrich Krotz describes as mediatized culture (2001). While Baacke's model contains a more pragmatic view which focusses on the skills one needs to use the variety of media, Masterman, Thoman/ Jolls/Wilson and Jörissen/Marotzki turn their focus more on the individual lifelong learning. That individual needs competencies to navigate his/her life as an active and participating citizen in a mediatized world. Referring Masterman, these necessary competencies will be gained through formal teacher education in schools. Education and media education are seen as inextricably linked to empower the individual in today's mediatized world. 


\subsection{Agency}

Any of the four models aims to encourage people to take (more) responsibility and control for their own lifelong learning process (in mediatized societies). Being educated in this case means a change in the way individuals perceive the world and themselves. It means to be empowered, to have gained orientation and behaviour patterns - resiliency - to be able to cope with less and less predictable surroundings (i.e. technologies, biographies). Therefore content, in media (literacy) learning, is a means to an end. That end is the development of transferable analytical tools rather than an alternative content.

\subsection{Structures}

Despite the above-mentioned similarities, the concepts clearly differ in their elementary structures but also build on each other's elements. Masterman's model as well as the model of Jörissen/Marotzki both see media as mediators. Media do not reflect the world but re-present it. Therefore, media essentially determine the structure of worldviews, both at a cultural and at an individual level. Following Jörissen/Marotzki, each technology brings different possibilities of articulation which, following Masterman, makes it neccessary to learn to decode media sign systems. Baacke and Thoman/Jolls/ Wilson identify several elements to explore the global symbolic media system. According to Thoman/Jolls, the exploration has to question media content in terms of authorship; techniques, format and technology; audience; framing and content; and purpose. In Baacke's model these elements can be summarized in the dimension of Media Knowledge in combination with the dimension of Media Critiques, that takes into account a reflection on consequences. Baacke's pragmatic model is the only one in which the way of gaining media literacy is considered (dimension of Media Production).

\subsection{Objectives}

The ultimate goal of all four media literacy models is to make wise choices possible. But new technologies arise and mediatized cultural worlds emerge. For this reason, existing knowledge cannot be simply transmitted and conventionally taught anymore. Steady personal development is required and therefore people need skills on a more abstract and transferable level. According to the models of Baacke as well as the model of Thoman/ Jolls/Wilson this should be a systematic approach that helps all citizens to better assess and evaluate their risks and rewards, individually and in community.

\subsection{Critical analytical ability as key competency}

Since the models have such different structures, we found it difficult to identify consistent key competencies. A critical analytical ability could be identified as the core competency that is central to all four models: «media criticism on an analytical level» (Baacke), «transferable analytical tools» (Masterman), "gaining orientation and behaving in a critical participatory way» (Jörissen/Marotzki), and "provides a common base for critical analysis of the global symbolic media system» (Jolls/ Wilson).

The models of Masterman and Jörissen/Marotzki are moving on a meta-level, addressing the general meaning of media education. Jörissen/Marotzki remain on the theoretical level. Masterman goes further and specifically mentions how teachers behave pedagogically to support the learning and maturing process. The concrete competencies of what it takes to live as a self-determined individual in a mediatized society, describes Baacke. Although Baacke's model is often depicted as shortened to the four dimensions, it also starts from the meta-level, namely the general meaning of a communicative competency. Practical instructions on how to understand the media system and thus to demonstrate a critical analysis are given by Jolls/Wilson with their concrete Q/TIPS. Their media literacy model is thus mainly on a level of practical formulation and recommendations for action for any kind of media usage setting and learning setting.

The comparison has, in addition to the findings above, produced further exciting meta-insights. These seem to be also of great importance to the international discourse on media literacy competencies, as they help to understand the different national frameworks to promote media literacy learning.

\section{MEDIA LITERACY LEARNING AS CROSS- DISCIPLINARY TASK}

The comparison has shown that there are different preconditions for the promotion of media literacy in the different countries. Media literacy learning can take place in formal, non-formal or informal learning settings. Learning in a formal setting is defined as curricular learning that takes place in education institutions and leads to degrees and qualifications. For example, the teaching of media and information literacy is anchored in formal education and in libraries in the USA. In Ger- 
many, the promotion of media literacy as part of media education was recently anchored in the federal school curriculums (KMK, 2012). Previously, the promotion of media literacy learning was primarily a task of institutions in the non-formal or informal education system in Germany. By definition learning in a non-formal setting takes place in an organized way (e.g. in civil society organizations, groups such as youth organizations or in music and sports courses). Participant certificates are either awarded or can be assigned within existing structures. Informal learning takes place integrated into everyday life contexts. Unlike formal and non-formal learning, informal learning is not necessarily intentional learning, which is why informal learning 'outcomes' are often - individually and socially - not or inadequately perceived. The professionals working in the libraries or community and youth centers can support both the non-formal and the informal media literacy learning. In Germany one finds institutions or initiatives that support media literacy (e.g. youth centers, community centers). People can attend computer courses or a video production course to gain media literacy competency. But media literacy learning also takes place in many informal learning settings as Abrahamsson (2018) shows for public libraries, where the professionals encourage visitors to find a work of art no longer subject to copyright or helping visitors to use mobile banking authentication. Abrahamsson shows, that the daily routines in libraries offer many interactive opportunities with the visitors for informal learning situations. The same applies to social work, community work and youth work where people come to ask for help and support - of cause not always concerning media but probably somehow related to the problem or the solution. Therefore, it is important to see that informal learning environments "play host for both traditional tasks and newer ones» (Abrahamsson, 2018, p. 10). To support people's understanding of how to use the digital tools, always leads back to traditional tasks as source criticism.

Professionals further can be motors and role models in reflexive media usage. They could show the possibilities that social media offer for participative and creative processes. They could show how to use social media to step up and articulate needs or support others in need. They also could motivate the clients / students to expand the range of use by using social media themselves in a more active and productive way. They could be a role model and encourage questioning and thinking critically. Professionals can offer themselves as contact persons, and be available and in touch for people's urgent needs (see Stix, 2019).

To foster the international discourse on promoting media literacy learning, we think it would be helpful to see the promotion of media literacy learning as a task for all helping professions in the social and educational system. Since the clients' / students' / visitor's lifes are highly influenced by media, media has to be taken into consideration in support processes for learning and helping. We recommend to see the promotion of media literacy learning as a cross-disciplinary task of all professions in the social support system. All kinds of social helpers like social workers, teachers, librarians, community workers etc. should support people to be able to navigate a mediatized landscape and to gain the necessary skills in formal, non-formal and informal learning settings.

This realization led us to further considerations. The considerations concern the common English terminologies «teaching media literacy» and «media literacy education». Given that media literacy rests on a continuum of knowledge, where 'mastery' is an everlasting quest, the concept of lifelong learning is an important part of advocating for media literacy.

\section{SHIFT IN TERMINOLOGY I: PROMOTING MEDIA LITERACY}

With realizing that the promotion of media literacy learning is not a task for professionals in formal learning settings everywhere, we questioned the common terminology of «teaching media literacy». Teaching is defined as activity in which "relatively complex contexts are explained to others in a longer process of argumentation» (Giesecke, 1997, p. 79). Teaching usually takes place in a certain distance to everyday life as it takes place in special places and the situations are kind of artificial. But in view of a mediatized everyday life in which young people acquire the most diverse knowledge in informal learning processes, the most important task for the teacher is to accompany the young people in their development, so that they can develop the resources and potentials they informally acquired in the organized education process. This goes hand in hand with the increasing questioning of teacher-centered teaching and the increasing consideration of student-centered learning scenarios. Teacher-centered instruction is where all the main impulses, actions and decisions come from the teacher. This is problematic as the students remain methodically and informally dependent on the teacher. They are predominantly receptive and initially limited in their criticism for lack of own knowledge and knowledge gain. In a student-centered lesson, on the other hand, learning is essentially determined by learners and their interests, questions, impulses and actions. The teacher rather assumes the role of the learning companion. The 
teacher turns from 'a sage on the stage to a guide at the side' and includes pedagogical actions of informing and advising. With this shift in consideration and having in mind that media literacy is a cross-disciplinary task for non-formal, informal, and formal learning settings, we saw that learning scenarios must be dialogical and no longer start from the omniscient teacher or social helper. Therefore, we strongly recommend to use the term "promoting media literacy learning» instead of "teaching media literacy», as we do already in this paper.

\section{MEDIATIZED SOCIETIES AND LIFELONG LEARNING}

We have already introduced the term mediatization above. At this point, we would now like to go into more detail on the underlying concept developed by Krotz and thus theoretically substantiate our thoughts in a first step. In a second step, we will show why it is important to understand media literacy as an element of lifelong learning.

Friedrich Krotz created the term mediatization (2001) to describe the phenomenon in which we realize that our societies and cultures have changed, with media being an integral part of our daily lives, and that media influence our social interaction and how we live together.

Krotz investigated how everyday life, identity, culture and society are influenced by the development of the media (Krotz, 2006, p. 62). He comes to the insight that media work in two ways. To a small extent, media have an effect on the content presented. To a greater extent, however, the media have an effect through their "communication potentials". This means that media influence people by the fact that people specifically orient themselves to media through their use of media. People orient their networks of relationships and their action spaces and produce themselves, their identity, as well as society and culture in a different way through media. People then perceive media differently and with different meanings than before (Krotz, 2007, p. 12 and Krotz, 2006, p. 62).

In other words, for Krotz, media technology developments and their cultural and social consequences have, above all, a social impact. The change results from the fact that more and more people differentiate their media usage habits and interests. Increasingly, they relate their social and communicative actions to a larger number of media (Krotz, 2001). According to Krotz, mediatization leads to cultural changes. He sees the technical starting point in the digitization and convergence of media as well as the associated emergence of new »communication potentials" (Krotz, 2001). People acquire media, make use of it for their own purposes and thus develop a self-evident everyday practice. Krotz's analysis concerning the importance of media is underlined by the vast numbers of people using media. According to the Internet World Stats (2019), there are 4.4 billion internet users all over the globe. Social media users, according to Clement / Statista (2018), stand at 2.77 billion. In the USA alone, this represents $72 \%$ of the population (PEW Research Center 2019). According to the German JIM-Study (mpfs, 2018), young people reported that they were online for an average of three and a half hours each day (mpfs, 2018, p. 31). The favorite websites and apps are currently the social media platforms YouTube, WhatsApp and Instagram (mpfs, 2018, p. 32).

This deep impact on people will continue as media technologies are changing continuously and rapidly, but this is a challenge for people to adapt to. Lifelong learning is called for, to be able to transfer and adapt old knowledge to new technological and social situations. Things that used to be said across the dinner table can now find their way online and be disseminated more widely. Lifelong learning does not only concern technological skills, but such ongoing learning also concerns acquiring social skills and understanding cultural norms. These and other related skills are generally understood through media literacy.

Thus, we think in mediatized societies it is important to see media literacy competency as part of a lifelong learning process. Media literacy is an important skill for any individual in a mediatized landscape to use media responsibly, in a considered, reflective and purposeful way suitable for one's own needs and with regard of other's needs. In view of the continuously and rapidly developing technologies, it takes an ongoing effort to cope with the cultural and technological changes. Assuming that these competencies are developed, renewed, or adapted in a lifelong learning process, they can be developed in formal learning settings, but they can also be acquired in non-formal and especially in informal learning settings that complement each other.

But it is important to have in mind, that the social and educational system which provides these learning settings are mediatized as well.

\subsection{Mediatized social and educational systems}

Mediatization affects all social levels in which human interaction takes place. Various social and educational institutions already have embedded diverse types of media; the mediatization cause disruptive 
changes for social and educational institutions. Kutscher et al. (2015) illustrate this process based on their triangular model Dimensions of Mediatization in Social Work:

Starting from the three corners (clients, professionals and organizations), the authors show the mediatized dimensions between and within the corners. For example, professionals exchange information with one another in specialist forums or via mailing lists. Professionals offer clients online advice, they show opportunities for participation and also provide them with relevant information about the organization (Kutscher et al., 2015, p. 4). The use of specialized software in processes of diagnostics, planning, documentation and evaluation of interventions also shows the influence of mediatization in social work (Kutscher et al., 2015, p. 3f.).

Although this triangle applies by way of example to the field of social work, it can nevertheless be transferred to other social and educational institutions. The institutions must adapt to the changed conditions. They have to be prepared for the fact that the help or support people are looking for has to do with the media itself, media usage, and communication. It becomes obvious that the actions of the professionals must adapt to the changed, mediatized conditions on the one hand and on the other hand they also co-create these conditions. Mediatization creates new tasks for the professionals not only at the organizational level, but also and especially in the interaction with the clients / students / visitors.

\section{SHIFT IN TERMINOLOGY II: MEDIA LITERACY LEARNING}

Consequently, in this paper we are avoiding the terms of «media literacy education", and preferably use the term of «media literacy learning». Our approach puts the (self-)learning individual at the center and not the imparting of knowledge by the teacher. We define learning as an active process of acquiring new knowledge or skills or expanding it. With the term education, we associate it with a passive attitude of the educated person or as a result, based on the everyday verbal use of the word. To educate means to experience education as a 'treatment'. This person is therefore passive, and can be seen metaphorically as a 'container' fed with knowledge. To be educated, on the other hand, denotes the result. Both interpretations contradict our previous arguments that media literacy is part of a lifelong self-directed learning process. In German, this process is also referred to as 'self-education'. However, in order to ensure a clear conceptual distinction, we have decided against this term and for the concept of media literacy learning. Last but not least, education is often associated with educational institutions. With avoiding the term media literacy education, we like to illustrate and underline, that media literacy is nothing to be learned only in educational institutions. It is a cross-disciplinary task for all educational AND social institutions.

\section{CONCLUSION}

This paper started with a comparison of different prominent models of media literacy and ended with fundamental considerations on the appropriateness of certain terms.

The four media literacy models presented have in common that they consider media literacy to be important for a self-determined life in a mediatized culture. All models therefore aim at empowering people and 'to make wise choices possible' - not only in the present but especially in the future. This means that there is a need for competencies that are also transferable to pending technological developments. Consequently, critical thinking could also be identified as a core competence of the four media competence models analyzed.

The analysis of the four models has also shown how important it is to understand media literacy learning as a cross-disciplinary task and no longer to see it as a task for schools alone. It is much more important that all areas in which people are offered social support also impart basic media literacy skills. Media literacy learning thus covers all areas of formal, non-formal and informal learning. We therefore recommend making this explicit in a terminology shift and using the term "promoting media literacy» instead of the term «teaching media literacy».

In the follow-up to the previous discussions, we argue that, in view of a constantly technologically evolving mediatized culture, it is also important to consider media literacy learning as part of lifelong learning. Following on from this and the considerations above on informal learning and the role of active learners, we point out that it is also conducive to the professional discourse to use the term "media literacy learning» rather than the term "media literacy education».

We believe that due to the different structures in the educational systems of the different countries and the consequently different classification of media literacy learning, the international discourse benefits from establishing the term "promoting media literacy learning» and we hope to have raised readers' awareness with this paper. 


\section{REFERENCES}

Abrahamsson, A. (2018). Old methods - new media and tools. Noll, 27(3), 9-10.

Baacke, D. (1996). Medienkompetenz - Begrifflichkeit und sozialer Wandel. In A. Rein (Ed.), von Medienkompetenz als Schlüsselbegriff (pp.112-124). Klinkhardt.

Baacke, D. (2001). Medienkompetenz als pädagogisches Konzept. In Gesellschaft für Medienpädagogik und Kommunikationskultur (GMK) (Ed.), Medienkompetenz in Theorie und Praxis. Broschüre im Rahmen des Projekts ,Mediageneration - kompetent in die Medienzukunft' (gefördert durch das BMFSFJ). Bielefeld.

Clement, J. (2018). Number of social media users worldwide from 2010 to 2021 (in billions). Statista. Retrieved July $8^{\text {th }}$, 2019, from https://www.statista. com/statistics/278414/number-of-worldwide-socialnetwork-users/

Gapski, H. (2001). Medienkompetenz. Eine Bestandsaufnahme und Vorüberlegungen zu einem systemtheoretischen Rahmenkonzept. Westdeutscher Verlag.

Giesecke, H. (1997). Pädagogik als Beruf: Grundformen pädagogischen Handelns (6th ed.). Juventa.

Internet World Stats (2019). Internet Users in the World. Retrieved July $8^{\text {th }}, 2019$, from https://www.internetworldstats.com/stats.htm

Jolls, T., \& Wilson, C. (2014). The Core Concepts: Fundamental to Media Literacy Yesterday, Today and Tomorrow. Journal of Media Literacy Education, 6(2), 68-78. http://dx.doi.org/10.23860/JMLE-2016-06-02-6

Jörissen, B. (2013). Medienbildung in 5 Sätzen. Retrived December $6^{\text {th }}, 2018$, from https://joerissen.name/ medienbildung/medienbildung-in-5-satzen/

Jörissen, B., \& Marotzki, W. (2009). Medienbildung - eine Einführung. Theorie - Methoden - Analysen, Klinkhardt.

KMK - Kultusministerkonferenz (2012). Medienbildung in der Schule (Beschluss der Kultusministerkonferenz vom 8. März 2012 / Resolution of the Conference of Ministers of Education and Cultural Affairs of 8 March 2012). Retrived August $7^{\text {th }}$, 2019, from https://www. $\mathrm{kmk}$.org/fileadmin/Dateien/veroeffentlichungen_ beschluesse/2012/2012_03_08_Medienbildung.pdf

Krotz, F. (2001). Die Mediatisierung des kommunikativen Handelns. Der Wandel von Alltag und sozialen Beziehungen, Kultur und Gesellschaft durch die Medien. Westdeutscher Verlag.

Krotz, F. (2006). Mediatisierung und Globalisierung als Wandlungsprozesse und die so genannte digitale Spaltung. Konzepte und Visionen für eine Medienpädagogik der Zukunft. In D. Wiedemann \& I. Volkmer
(Eds.). Schöne neue Medienwelten (pp. 60-69). Grin.

Krotz, F. (2007). Mediatisierung. Fallstudien zum Wandel von Kommunikation. Springer VS.

Kutscher, N., Ley, T., \& Seelmeyer, U. (2015). Mediatisierung (in) der Sozialen Arbeit. Schneider-Verlag Hohengeren.

Masterman, L. (1989). Media Awareness Education: Eighteen Basic Principles. Retreived December $6^{\text {th }}, 2018$, from http://www.medialit.net/reading-room/mediaawareness-education-eighteen-basic-principles

Morgenthaler, D. (2010). Len Masterman Interview Transcript. Voices of Media Literacy International Pioneers Speak. Retreived December $6^{\text {th }}, 2018$, from https://www.medialit.org/reading-room/voices-medialiteracy-international-pioneers-speak-len-mastermaninterview-transcriptn

mpfs (Medienpädagogischer Forschungsverbund Südwest) (2018). JIM. Jugend, Information, (Multi-) Media. Retrieved August $7^{\text {th }}, 2019$, from https://www. mpfs.de/studien/jim-studie/2018/

Pew Research Center (2019). Social media use over time. Surveys conducted 2005-2019. Retrieved August $7^{\text {th }}$, 2019, from https://www.pewresearch.org/internet/ fact-sheet/social-media/

Stix, D. C. (2019). Schleichende Grenzaufweichungen und persönliche Verflechtungen. Strategien im pädagogischen Handeln mit Social-Media-Plattformen in der Offenen Kinder- und Jugendarbeit. Zeitschrift für Sozialpädagogik/ZfSP, 17(2), 167-185.

Thoman, E. (1993). Skills and Strategies for Media Education. Retrieved August $7^{\text {th }}, 2019$, from http://www. medialit.org/reading-room/skills-strategies-mediaeducation 